\title{
The Analysis of Marketing Mix Strategy Effect on Students Decision to Choose Faculty Economics and Business of Universitas Dharmawangsa Medan
}

\author{
Marleny Syam; Baby Karina Fawzeeya Sembiring; Linda Trimurti Maas
}

Master of Management Study Program; Postgraduate School of University of Sumatera Utara, Indonesia

http://dx.doi.org/10.18415/ijmmu.v6i6.1173

\begin{abstract}
The education and learning world is one of the development aspects to improve the quality of human resources so that they will be capable to develop themselves. Therefore, every human being is compulsory to learn, whether through formal or informal system. Service marketing mix strategy, especially education services concerning service marketing for higher education is inseparable from the discussion of products (study programs), prices, promotions, places, people, processes and physical evidence. The attraction of marketing mix factors that influence the decisions of university student candidates in choosing the Faculty of Economics and Business, Universitas Dharmawangsa University, Medan. This service marketing mix strategy will determine the student's decision in choosing. Therefore, which marketing mix strategy influences students' decisions in choosing the Faculty of Economics and Business at Universitas Dharmawangsa. Samples of Respondents were seventy-four students of the Faculty of Economics and Business, Universitas Dharmawangsa, Medan. By applying the Partial Least Squares - Structural Equation Model (PLS-SEM) with the SmartPLS V3.2.8 tool, the conclusion of the research results showed that there was a positive and significant effect of price on the decisions in choosing Faculty of Economics, Universitas Dharmawangsa of Medan, positive but insignificant influence between products, promotions, places, people, processes and physical evidence on the student's decision to choose the Faculty of Economics, Universitas Dharmawangsa, Medan. The method of data collection was conducted by documentation, interviews and distribute questionnaires to respondents.
\end{abstract}

Keywords: Marketing Mix; Decision to Choose; Consumer Behavior

\section{Introduction}

Education and learning are the main keys to improving the quality of self. Both formal and non formal education, they are play an important role. Therefore education has been taught from an early age, both related to character, mental to general knowledge which will be very useful in economic competition as it is today. This is the background of the emergence of various educational institutions in all fields to meet human needs for science and win competitions. Universities and colleges as the highest institution of education, they having an important role in printing superior human resources, and competing to be the best institution to realize this. 
In terms of business, education is also a "wetland" that can bring high profits by managed properly. People who are hungry for education are captive markets, especially supported by work requirements which has an admission minimum standard of employees who have graduated. So it cannot be denied, higher education is an excellent business field.

This phenomenon being the background of conducting this research, how the Faculty of Economics and Business University of Dharmawangsa Medan is able to compete with the faculties within the University of Dharmawangsa Medan itself, and compete with the same faculty in other universities both private universities and State Universities. This is also supported by data on admissions for economics and business faculties that have declined since 2016-2018. By using the ideal model of academic quality as a reference for analysis and seeing the increasingly fierce competition between private universities, this issue is increasingly interesting to study. There are private universities efforts to improve academic quality, but the business that appears at this time is only the extraction and development of existing resources, not up to quality improvement yet, pricing, appropriate promotion, suitable location, competent human resources, appropriate processes and physical evidence which is an important part of marketing.

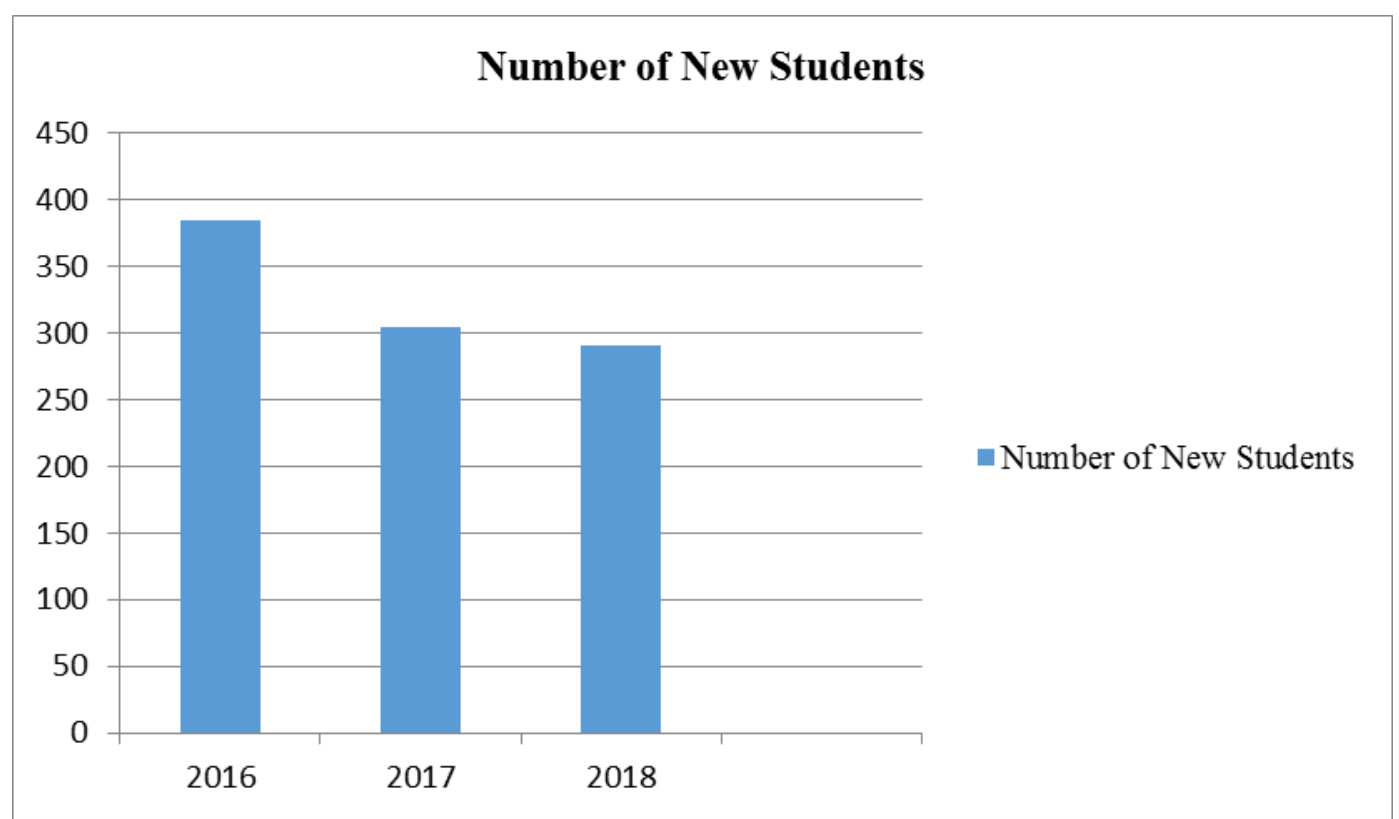

Figure 1. Growth Chart of Faculty of Economy and Business University of Darmawangsa Medan Students on 2016-2018

Sunyoto (2014) stated that the definition of marketing is the spearhead of companies in an increasingly fierce world of competition, companies are required to stay alive and develop. According to Kotler and Keller (2016) the marketing mix strategy is inseparable from the discussion of products / study programs, prices, promotions, places, people, processes and physical evidence. In the marketing mix there are a set of marketing tools known in the $4 \mathrm{P}$ term, namely product, price, place, and promotion, while in marketing services have several additional marketing tools such as people), process (physical) and physical evidence (physical evidence), so that it is known as 7P, it can be concluded that the service marketing mix is product, price, place, promotion, people, process and physical evidence. The attraction of marketing mix factors that influence the decision of prospective students in choosing the Faculty of Economics and Business, University of Dharmawangsa, Medan. 


\section{Product}

According to Soedijati and Pratiminingsih (2011) states that products in higher education are more often referred to as education programs or services. The program is the most basic thing in higher education institutions. According to Contantin (2011), products can be seen from two perspectives, namely: if students are consumers, products lead to services offered by universities to meet the needs of students, while the job market as consumers, students are products from universities.

\section{Price (Education Fee)}

According Mulyono (2010) Cost is the amount of money that is provided or allocated and used or spent for the implementation of various functions or activities in order to achieve a goal and objectives within the framework of the management process. The cost of education can be said as one of the important factors in the process of providing education, if there is no support from education cost, the process of providing education will be disrupted.

\section{Promotion}

According to Lupiyoadi and Hamdani (2006), Promotion is one of the variables in the marketing mix that is very important to be carried out by companies in marketing service products. Promotional activities not only function as a communication tool between the company and consumers, but also as a tool to influence consumers in purchasing or using services in accordance with their desires and needs.

\section{Place (Location)}

According to Swastha in Wulandari (2013), Location is a place where a business or business creativity is carried out. Important factors in developing a business are the location, which is near by urban areas, how to get there and travel time to get location. Ease of access to tertiary institutions, location not so far from the center of city and easy access to important objects. It could influence the decision making of prospective students to choose the tertiary institution.

\section{Person}

People are all actors who play an important role in the presentation of services so that they can influence the buyer's perception. Elements of people are company employees, consumers, and other consumers. According to Payne (2001), that the importance of people in service marketing leads to greater interest in internal marketing. It realizes the importance of attracting, motivating, training and maintaining employee quality by developing jobs to satisfy individual needs.

\section{Process}

According to Yazid (2003), that the process is all the actual procedures, mechanisms and flow of activities. The service process is a major factor in the service marketing mix. A customers will be happy to feel the service delivery system as part of the service itself. The process in accordance with research at the University is started from the admission procedure to the new enrollment process to become a student of the Faculty of Economics and Business at Dharmawangsa University, Medan. 


\section{Physical Evidence}

Physical evidence is included in the process of providing educational services. Physical evidence is a supporting factor in determining the decision of prospective students in choosing the tertiary institution to be entered. Among them is the process that begins with a visit to see buildings, lecture halls, libraries, computer laboratories and humans, where service providers and consumers interact and each tangible component facilitates the appearance or communication of these services (Kalsum, 2010).

\section{Decision to Choose}

The decision is to make a choice between two or more alternatives. Decisions can also be interpreted as a result of the fraction of the problem, but in the process must be based on logic and consideration, determining the best alternative, and approaching the goals that have been made previously. This decision is clearly related to the marketing mix, because this decision will establish a marketing mix strategy that will implement by universities to achieve a goal that has been planned.

Based on the phenomena of higher education institutions and marketing mix variables, the research conceptual framework can be arranged as follows:

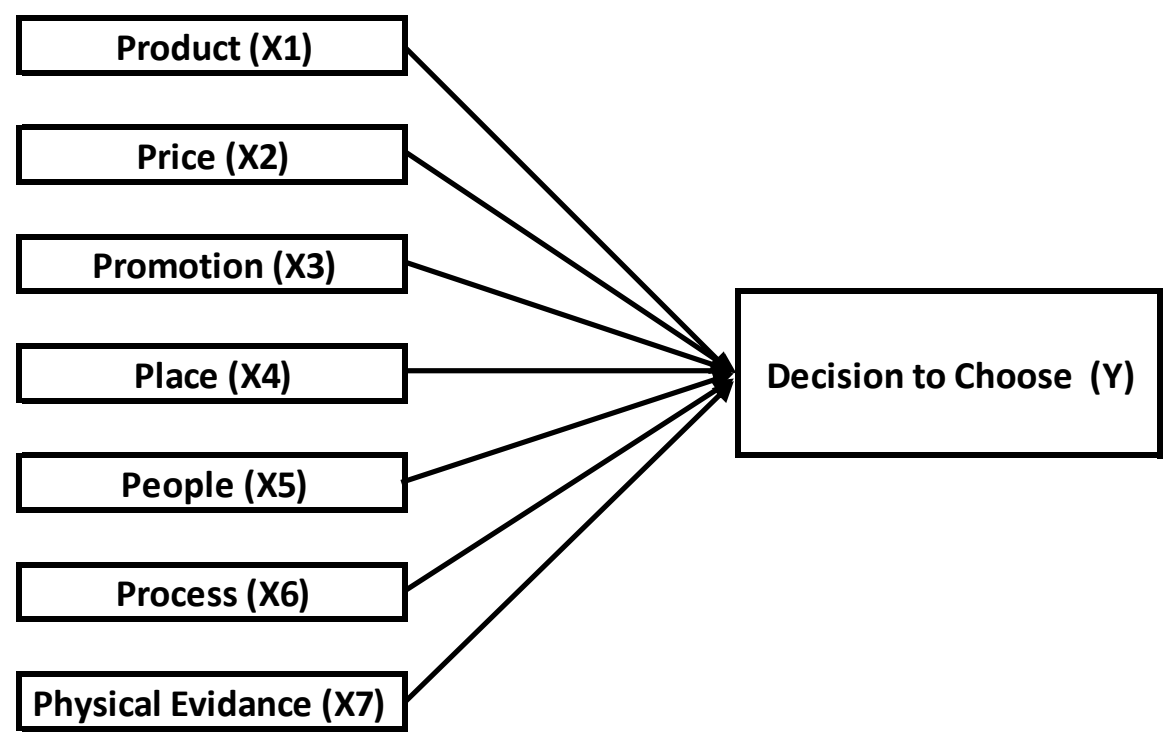

Figure 2. Conceptual Framework

\section{Research Methode}

This type of research is quantitative descriptive. The study takes location at Faculty of Economics and Business, University of Dharmawangsa, Medan. The population are students of the faculty of business economics with a total of 291 students in the 2018/2019 school year. The sampling technique uses purposive sampling. Purposive sampling is a sampling technique with certain considerations (Sugiyono, 2014). The type of sample is homogeneous, so for the sample size determined using the Slovin formula as many as 74 students. 
The data used are primary and secondary data. Primary data were obtained using a questionnaire instrument with calculations using a Likert Scale. While secondary data used in the form of evidence, notes, or historical reports that are arranged in published archives. namely complementary or reference books, magazines, journals, official reports from companies and lecture notes relevant to the problem under study. Testing data by applying the Partial Least Squares - Structural Equation Model (PLS-SEM) with the SmartPLS V3.2.8 tool.

\section{Result and Discussion}

\section{Outer Model Test}

Based on the Outer Model Test results that the data tested showed a high level of validity and reliability through convergent validity and discriminant validity tests. Cross Loading data shows the overall value above 0.50. Likewise with the data on the Cronbach's Alpha test and Composite Reliability overall showed results above 0.70. Average Variance Extracted (AVE) value also shows a good level of validity where all data have values above 0.50 .

\section{Inner Model Test}

The inner model test is performed using the R Square Test and $\mathrm{T}$ Value Test. The R square test result showed The Decision to Choose (Y) Variable has a value of $R$ square $=0.967$ which means it shows a strong influence. The Decision to Choose $(\mathrm{Y})$ Variable that can be explained by the product variable $(\mathrm{X} 1)$, price $(\mathrm{X} 2)$, promotion $(\mathrm{X} 3)$, place $(\mathrm{X} 4)$, person $(\mathrm{X} 5)$, process $(\mathrm{X} 6)$, physical evidance $(\mathrm{X} 7)$ are $96.7 \%$ while the rest $3.3 \%$ is explained by other variables outside the study.

$\mathrm{T}$ Value Test is used to test the directly effect and the indirectly effect. In this study, only direct effect will be tested through the PLS Boothstapping process.

Table 1. Direct Effect Test

\begin{tabular}{|l|r|r|r|r|r|}
\hline Variable & $\begin{array}{c}\text { Original } \\
\text { Sample } \\
(\mathbf{O})\end{array}$ & $\begin{array}{c}\text { Sample } \\
\text { Mean } \\
(\mathbf{M})\end{array}$ & $\begin{array}{c}\text { Standard } \\
\text { Deviation } \\
(\text { STDEV) }\end{array}$ & $\begin{array}{c}\text { T Statistics } \\
(\mid \mathbf{O} / \text { STDEV|) }\end{array}$ & $\begin{array}{c}\text { P } \\
\text { Values }\end{array}$ \\
\hline Product (X1) -> Decession to Choose (Y) & -0.001 & -0.002 & 0.051 & 0.016 & $\mathbf{0 . 9 8 7}$ \\
\hline Price (X2) -> Decession to Choose (Y) & 0.996 & 0.995 & 0.027 & 36.372 & $\mathbf{0 . 0 0 0}$ \\
\hline Promotion (X3) -> Decession to Choose (Y) & 0.013 & 0.013 & 0.037 & 0.352 & $\mathbf{0 . 7 2 5}$ \\
\hline Place (X4) -> Decession to Choose (Y) & -0.023 & -0.025 & 0.031 & 0.734 & $\mathbf{0 . 4 6 3}$ \\
\hline People (X5) -> Decession to Choose (Y) & 0.021 & 0.018 & 0.042 & 0.499 & $\mathbf{0 . 6 1 8}$ \\
\hline Process (X6) -> Decession to Choose (Y) & 0.021 & 0.024 & 0.048 & 0.446 & $\mathbf{0 . 6 5 6}$ \\
\hline $\begin{array}{l}\text { Physical Evidance (X7) -> Decession to } \\
\text { Choose (Y) }\end{array}$ & -0.054 & -0.049 & 0.036 & 1.518 & $\mathbf{0 . 1 3 0}$ \\
\hline
\end{tabular}

Source: Processed Research Data (2019) 
According to the results of the boothstrapping presented in Table 1, we conclude the relationship between variables directly (direct effect) as follows:

1. The influence of product variables (X1) on the decision to choose variable (Y) states a positive relationship but not significant which is shown through the T-value of 0.016 under the rule of thumb 1.65.

This result was also strengthened by the questionnaire test which showed respondents' answers by $23 \%$ expressed strongly agree, and 53\% agreed to product variables. While the condition is not significant, due to the presence of other excellent products from the University of Dharmawangsa Medan, namely other faculties that have a greater competitive advantage, such as the Faculty of Law which has more students than the Faculty of Economics and Business (FEB). In addition, FEB competition between universities also has a significant impact on the decision to choose prospective students today. FEB on University of Dharmawangsa also has not optimally innovated on teaching and learning facilities and infrastructure. This is supported also by the statement of respondents who answered Neutral and Disagree at $24 \%$.

2. The influence of the price variable (X2) on the decision to choose variable (Y) states a positive relationship and significant which is indicated through the T-value of 36.372 above the rule of thumb 1.65.

This result was also strengthened by the questionnaire test which showed respondents' answers by $29 \%$ expressed strongly agree, and $48 \%$ agreed to the price variable. While the variable price becomes significant due to the offer of entrance fees and tuition at the Faculty of Economics and Business, University of Dharmawangsa, Medan, which is relatively affordable and becomes a competitive advantage with other universities. Price is one of the main considerations in choosing study programs and universities, especially for prospective students and students who come from middle to lower economic families. Where on one hand, the desire to continue education to a higher level is very large, especially in the city of Medan. Based on the results of the respondent's answer test, it can be assumed that one of the main reasons students choose the Faculty of Economics and Business, University of Dharmawangsa, Medan is because the cost of entry and tuition is affordable and supported by the tuition payment method that can be paid in installments.

3. The influence of the promotion variable $(\mathrm{X3})$ on the decision to choose variable $(\mathrm{Y})$ states a positive relationship but not significant which is indicated through the T-value of 0.352 under the rule of thumb 1.65 .

This result was also strengthened by the questionnaire test which showed respondents' answers by $21 \%$ expressed strongly agree, and $46 \%$ agreed to the promotion variable. While the condition is not significant, due to promotion from the Faculty of Economics and Business, University of Dharmawangsa, Medan, it has not used informative information technology. Promotion is one of way to obtain information in choosing study programs and universities, especially for prospective students and students who come from middle to lower economic families. This is supported by the statement of respondents who answered neutral $(\mathrm{N})$ with an average value of respondents' answers of $27 \%$. 
4. The influence of place variables $(\mathrm{X} 4)$ on the decision to choose variable (Y) states a positive relationship but not significant which is indicated through the T-value of 0.734 under the rule of thumb 1.65.

This result was also strengthened by the questionnaire test which showed respondents' answers by $29 \%$ expressed strongly agree, and $41 \%$ agreed to place variables. While the condition is not significant, due to the location of the Faculty of Economics and Business, University of Dharmawangsa, Medan, it is still not strategic. The location is quite far from the city center and public transportation access, giving its own consideration to prospective students to choose. This is supported by the statement of respondents who answered neutral $(\mathrm{N})$ with an average value of respondents' answers of $24 \%$ and $5 \%$ disagree.

5. The influence of the variable person (X5) on the decision to choose variable (Y) states a positive relationship but not significant which is shown through the test of the $T$-value of 0.499 under the rule of thumb 1.65 .

This result was also strengthened by the questionnaire test which showed respondents' answers by $33 \%$ expressed strongly agree, and $46 \%$ agreed to variable people. While the condition is not significant, due to the quality and quantity of employees, lecturers, students of the Faculty of Economics and Business, University of Dharmawangsa Medan, which is not perfect yet, including staff and employee services for students to be taken into consideration. Specifically for the existence of alumni, which at this time has not information or publishing shown many roles and evidence of success in both business and community environments. This is supported by the statement of respondents who answered neutral $(\mathrm{N})$ with an average value of $18 \%$ of respondents' answers and $3 \%$ disagreed.

6. The influence of the process variable (X6) on the decision to choose variable (Y) states a positive relationship but not significant which is indicated through the T-value of 0.446 under the rule of thumb 1.65.

This result was also strengthened by the questionnaire test which showed respondents' answers by $24 \%$ expressed strongly agree, and $48 \%$ agreed to process variables. While the condition is not significant, due to the admission process, teaching and learning activities, and the release of students, it has not been carried out effectively yet. One of them is for example the registration process of study plans and semester payments are still manual where competitors already use digital networks. This is supported by the statement of respondents who answered neutral $(\mathrm{N})$ with an average value of $28 \%$ of respondents' answers and $3 \%$ disagreed.

7. The influence of physical evidence variable $(X 7)$ on the decision to choose variable $(Y)$ states a positive relationship but not significant which is shown through the $T$-value of 1.518 under the rule of thumb 1.65.

This result was also strengthened by the questionnaire test which showed respondents' answers by $21 \%$ expressed strongly agree, and $32 \%$ agreed to physical evidence variables. While the condition is not significant, due to the condition of teaching facilities and learning facilities is still inadequate, the lecture building is still not completely renovated. Physical appearance is one of the important selling points that directly gets value from prospective students. This is supported by the statement of respondents who answered neutral $(\mathrm{N})$ with an average value of respondents' answers of $16 \%$ and as much as $2 \%$ disagreeing and strongly disagreeing as much as $3 \%$.

The Analysis of Marketing Mix Strategy Effect on Students Decision to Choose Faculty Economics and Business of Universitas Dharmawangsa 


\section{Conclusion}

According to the results of the study it can be concluded and suggested to the dean of the Faculty of Economics and Business University of Dharmawangsa Medan and subsequent researchers are:

1. Conduct research on the student needs of study programs, so that they can become references in making plans to open new majors.

2. The marketing team is expected to make programs on a regular basis whose purpose to improve communication and closeness (customer intimacy) in order to obtain information related to other needs.

3. In addition, simultaneously always providing understanding, both in the form of outreach and propaganda directly or through social media networks about the benefits, the purpose of studying at the Faculty of Economics and Business at University of Dharmawangsa Medan.

4. Increase promotion by visiting high school by inviting parents, especially twelfth grade, to continue their studies. Providing information, objectives and advantages of the Faculty of Economics and Business, University of Dharmawangsa, Medan and cross selling, for example by giving a discount coupon to the first registrant so as to ease the cost of registration.

5. Use the social media effectively and make it as attractive as possible so that prospective students can easily receive information.

\section{References}

Agus Irawan dan ikhwan Faisal (2014), Analisis Pengaruh Bauran Pemasaran Jasa Terhadap keputusan Memilih Program Studi (Studi pada Jurusan Akuntansi dan Jurusan Administrasi Bisnis di Politeknik Banjarmasin).

Ambarkahi, Y. (2007). Faktor Bauran Pemasaran Jasa Yang Dipertimbangkan Mahasiswa Dalam Memilih Kuliah di Politeknik Negeri Jember. Jurnal bisnis dan Manajemen, 339 - 347.

Andriani,Kusumawati (2013). A Qualitative Study of the factors Influencing Student Choice: The case of Public Univeristy in Indonesia,Journal of Basic and applied Scientific Research.

Buchori, Alma. (2007). Manajemen Pemasaran dan Pemasaran Jasa . Bandung : Alfabeta

Buchori, Alma. (2011). Manajemen Pemasaran dan Pemasaran Jasa . Bandung : Alfabeta

Contantin,Ioan ( 2012). Marketing Higher Education Marketing Mix: The 7PS Framework, Bulletin of the Transilvania University Of Brasov. Vol 4 (53).No 1. Series V:Economic Science 23-30

Elliot, Kevin., dan Margaret A. Healy. 2001. Key Factor Influencing Student Satisfaction Related to Recruitment and Retention, Journal of Marketing for Higher Education. Volume 10 Number 4

Ghozali, Imam dan Hengky Latan. 2015. Konsep, Teknik, Aplikasi Menggunakan Smart PLS 3.0 Untuk Penelitian Empiris. BP Undip. Semarang.

Hevi,Hendri John.2013.Pengaruh Struktur Organisasi dan Sistem Informasi Majemen Terhadap Pengambilan Keputusan Manajemen .Bandung:Universitas Komputer Indonesia 
Hoyt, Jeff E \& Andrea, B Brown(2003). Identifying Colleg Choice Facotrs to Successfully Marekt Your Institution, College and University Journal, Vol .78.No. 4

Ismanto, Juli . 2017. Analisis pengaruh persepsi mahasiswa memilih perguruan tinggi IPWIJA Program S2 (Pasca Sarjana).

Kalsum, Eka Umi. 2010. Analisis Srategi Bauran Pemasaran Terhadap Keputusan Mahasiswa Memilih Fakultas Ekonomi Univeristas Al Azhar Medan

Kotler, Philip and Kevin Lane Keller, 2012, Marketing Management, 14th Ed., Pearson Education, Inc., publishing as Prentice Hall, One Lake Street, Upper Saddle River, New Jersey 07458.

Kotler,Philip \& Amstrong,Gary (2014): Prinsip-prinsip Manajemen,Edisi 14,Jilid 1,Jakarta:Erlangga

Kotler,Philip \& Kevin L. Keller (2016): Marketing Management,15th. Edition New Jersey:Pearson.

Kotler,Philip 2000: Marketing Management,The Millennium First Edition. New Jersey:Prentice Hall.

Lovelock. C. H., \&. W. (2005): Manajemen Pemasaran Jasa.Jakarta PT.Indeks kelompok Gramedia.

Lupiyoadi, Rambat. 2014. Manajemen Pemasaran Jasa Berbasis Kompentensi Edisi Ketiga. Jakarta: Salemba Empat.

M.Arsyad (2010). Analisis Pengaruh Marketing Mix Terhadap Keputusan Mahasiswa Memilih Akpindo Jakarta.

Minarti,Sri.2012; Manajemen Sekolah Mengelola Lembaga Pendidikan Secara Mandiri Yogyakarta: ArRuz Media

Mulyono. 2010. Konsep Pembiayaan Pendidikan. Yogjakarta : Ar Ruzz Media

Nugroho,Satriyo,2010; Analisis Pengaruh Pencitraan, Promosi dan Kualitas Pelayanan Terhadap Minat Kuliah di Diploma III Fakultas Ekonomi Universitas Diponegoro

Paskalis Dakhi ( 2017),Pengaruh Bauran Pemasaran Jasa Terhadap Keputusan Mahasiswa memilih kuliah di STIE Nias Selatan

Payne, Andrian. 2001. The Essence Of Service Marketing. Diterjemahkan oleh : Fandy Tjiptono, Edisi Pertama. Yogyakarta: Penerbit Andi.

Purnama, Lingga. 2001. Strategic Marketing Plan. Jakarta: PT. Gramedia Pustaka Utama.

Putri, Wulandini., dan Roni Saputra. 2017. Pengambilan Keputusan Mahasiswa Dalam Memilih Perguruan Tinggi Swasta di Pekanbaru.

R. Terry,George,(2006), Dasar-dasarManajemen,Bumi Aksara,Jakarta.

Rabbaniyah,Qiyadah.2014.Tesis.Manajemen Pemasaran Perguruan Tinggi di Stikes Madani.Yogyakarta: Pascasarjana UIN Sunan Kalijaga Strategic Marketing Plan. Jakarta: PT. Gramedia Pustaka Utama.

Rahardjo, Sis., dan Muhammad Riza Firdaus. 2015. Analisis pengaruh bauran pemasaran status sosial ekonomi dan motivasi terhadap keputusan mahasiswa dalam memilih kuliah ( studi pada Lembaga Pendidikan dan Pengembangan Profesi Indonesia ( LP3I ) Bussiness College _ Cabang Banjarmasin 
Rambat, Lupiyoadi dan A. Hamdani 2006. Manajemen Pemasaran Jasa.Edisi Kedua. Jakarta: Salemba Empat.

Rodic Lukic, Vesna., dan Nemanja Lukic. 2016.Application of marketing mix concept in student recruitment strategies: Evidence from University of Serbia.

Sinulingga,Sukaria.2013.Metode Penelitian.Edisi ke 3.Medan: USU Press.

Soedijati, E.K., \& Pratiminingsih,S.A.,2011. The Impact of Marketing Mix On Students Choice of of University , $2^{\text {nd }}$ International Conference On Bussiness and Economic Research Proceeding

Sugiyono, 2014. Metode Penelitian Kuantitatif, Kualitatif dan R\&D. ALFABETA. Bandung.

Sunyoto, Danang.2014; Konsep Dasar Riset Pemasaran dan Perilaku Konsumen Yogyakarta: center for academic publishing service.

Supriadi,Dede.2003; Satuan Biaya Pendidikan Dasar dan Menengah.Bandung: PT.Remaja Rosdakarya

Tim Dosen Administrasi Pendidikan Universitas Pendidikan Indonesia. 2011. Manajemen Pendidikan, Bandung: Penerbit Alfabeta

Tjiptono,Fandy.2014. Pemasaran Jasa. Yogjakarta : Andi Yogjakarta

Wulandari,Iken Mety. 2013.Pengaruh Brand Image dan Lokasi Terhadap Keputusan Calon Mahasiswa Melanjutkan Studi di Perguruan Tinggi (Studi Kasus Pada Siswa KelasXII SMAN Jurusan IPS Kota Jember)

Yazid. 2003. Pemasaran Jasa :Konsep dan Implementasi, Edisi Kedua. Yogyakarta: Penerbit Ekonisia Fakultas Ekonomi UII

Yenti Sumarni,Darmsnsyah,Sulastri Anggarawati. 2013. Anlisis Program Pemasaran Terhadap Proses Keputusan Mahasiswa Memilih Jurusan Pendidikan Agama Islam Fakultas Tarbiyah dan Tadris IAIN Bengkulu

\section{Copyrights}

Copyright for this article is retained by the author(s), with first publication rights granted to the journal. This is an open-access article distributed under the terms and conditions of the Creative Commons Attribution license (http://creativecommons.org/licenses/by/4.0/). 